\title{
連結制振構法を用いた建物の固有振動および減衰に関する基本特性 FUNDAMENTAL PROPERTIES ON EIGENVIBRATION AND DAMPING IN CONNECTED BUILDING STRUCTURES
}

\author{
満田衛資*1, 大㴊 充紀*2, 辻 聖晃*3, 竹脇 出*4 \\ Eisuke MITSUDA, Mitsunori OHBUCHI, Masaaki TSUJI \\ and Izuru TAKEWAKI
}

\begin{abstract}
Some fundamental properties are disclosed on eigenvibration and damping in connected building structures. A classification in terms of damping variation properties with respect to increased capacity of connected dampers is conducted by using complex eigenvibration analysis. There exist several regions in the plane of mass ratio and stiffness ratio. In each region, the lowest-mode damping variation exhibits a different property with respect to increased capacity of connected dampers. These properties are useful in the design of the system of connected buildings.
\end{abstract}

Keywords: Connected building structure, eigenvibration, damping property, complex eigenvalue analysis, viscous damper, domain classification 連結制振，固有振動，減衰特性，複素固有值解析，粘性ダンパー，領域分類

\section{1. 序}

建物の耐震性能の向上を図る連結制振構法については, 基本的制振 特性の解明や最適ダンパー量の決定方法に関する多数の研究成果が 蓄積されており ${ }^{1-22)}$ ，実建物に対する適用例も存在する ${ }^{23,24)}$.

従来の連結制振に関する研究の多くは，2棟の建物を連結機構によ り連結する場合の，連結する建物間の最適な固有周期比や，連結機構 の最適特性を明らかにすることを主目的としている。これに対して， 本論文の目的は, 連結する 2 棟の建物の質量比および剛性比の関係に よって異なる固有振動特性および減衰特性を分類し, 固有値, 固有モ ードおよび減衰特性などに言及しながらその性質を明らかにするこ とである.

これまでに提案されている連結制振に関する理論的研究の代表的 なものとして, 定点理論 ${ }^{25)}$ を用いたものが存在する ${ }^{3-5,10)}$. 定点理論 により厳密に扱うことのできるモデルは基本的に構造減衰を有しな いモデルに限定される.

蔭山らは，2 棟の構造物をダンパーのみ，もしくはばねとダンパー を併用して連結し, 両棟の耐震性能の向上を目的として, 上述の定点 理論を用いた研究を展開している ${ }^{3-5)}$. ダンパーのみで 2 棟の構造物 を連結するときの構造モデルとしては, 連結制振の理想系である双方 の系の定点の伝達率の高さが等しくなるモデル（質量比と剛性比が反 比例の関係となるモデル) を主に扱っており, その質量比と剛性比に よる制約を緩和するために, 連結ばねとダンパーを併用したモデルを
扱っている. 一方, 本論文で想定するモデルでは, ダンパーのみで連 結する上で質量比および剛性比に制約を設けていないため、そのダン パー減衰係数をパラメターとして,より広範囲の質量比および岡性比 を有するモデルについて検討している．

楊らは, $2 つ の 1$ 質点系を接合ばねと接合ダンパーで連結した連結 構造物の主構造物の伝達関数のピークを最小にする最適接合ば齐剛 性と最適ダンパー減衰係数の決定方法について, 定点理論に基づく理 論を展開し, 質量比, 周波数比で定義される領域を 3 つに区分して, 各領域での最適值決定法を提案している ${ }^{10)}$ 。

しかしながら，これまでに, 連結制振系の固有振動数や減衰定数に 関する特性について理論的な観点から詳細に論じた研究は著者らの 知る限り存在しない. その理由として, 一般に複素固有值解析を必要 とするため, 理論的検討が困難であったことや, 連結ダンパー容量の 増加に対する特性変動の把握という視点が導入されなかったことが 挙げられる. 本論文では, 連結ダンパー容量増加に対する固有振動数 や減衰定数の特性について詳細に論じることを主目的としている.

本論文では, 質量比と剛性比を軸とする図において連結ダンパー容 量の増加に伴う減衰定数や固有振動数の変動の特徴に応じて領域分 けを行うが，その領域分けの図においては，実際の建築物では想定し がたい質量比および岡性比の範囲についても一部触れているものの， 多くの連結制振構法の建物モデルについてその固有振動特性を予測 することが可能となる. また，ある質量比および岡性比の建物モデル

\footnotetext{
*1 満田衛資構造計画研究所 京都大学大学院 博士課程 $\cdot$ 工修

*2 鹿島建設(株) 工修 (元 京都大学大学院 大学院生)

*3 京都大学工学研究科建築学専攻 准教授 - 博士 (工学)

*4 京都大学工学研究科建築学専攻 教授. 工博
}

Mitsuda Structural Consultants

Graduate Student, Kyoto Univ., M. Eng.

Kajima Corp., M. Eng.

Assoc. Prof., Dept. of Architecture and Arch. Eng., Kyoto Univ., Dr. Eng. Prof., Dept. of Architecture and Arch. Eng., Kyoto Univ., Dr. Eng. 
に対して得られる減衰定数の最大值およびそのときの連結ダンパー 減衰係数の最適值を導くことで, アウトフレーム連結制振構法におい て剛性比がある程度以上の值になると減衰定数の増加が望めなくな る ${ }^{21)}$ な゙゙の既往の研究の裏づけにもなり得る.

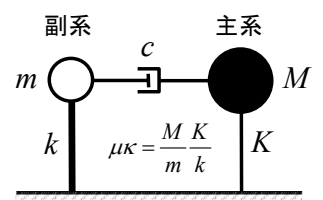

図 1 連結制振系の単純モデル

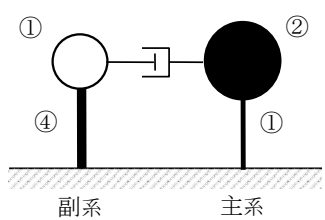

(a) モデル I $(\mu \kappa=0.5)$

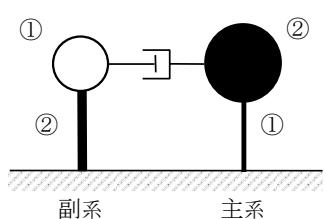

(b) 基本モデル $(\mu \kappa=1.0)$

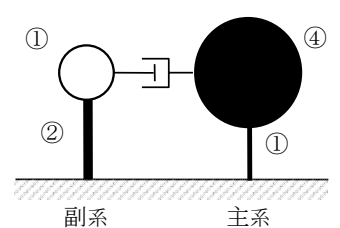

(c) モデル II $(\mu \kappa=2.0)$

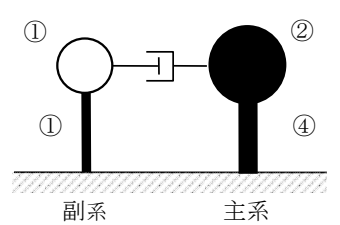

(d) モデルIII $(\mu \kappa=8.0)$
図 2 解析モデル概要（丸数字は、基本モデルにおける副系の質量と主系の 剛性を基準としたときの主系と副系の質量および剛性の比率)

表 1 解析モデル諸元

\begin{tabular}{|c|c|c|c|c|c|}
\hline \multirow{2}{*}{ モデル } & \multirow{2}{*}{ 副系 } & $\begin{array}{c}\text { モデル I } \\
\mu \kappa=0.5\end{array}$ & $\begin{array}{c}\text { 基本モデル } \\
\mu \kappa=1.0\end{array}$ & $\begin{array}{c}\text { モデル II } \\
\mu \kappa=2.0\end{array}$ & $\begin{array}{c}\text { モデル III } \\
\mu \kappa=8.0\end{array}$ \\
\hline \begin{tabular}{c} 
質量[t] \\
\cline { 3 - 6 }
\end{tabular} & 1000 & 2000 & 2000 & 4000 & 2000 \\
\hline $\begin{array}{c}\text { 岡性 } \\
{[\mathrm{kN} / \mathrm{mm}]}\end{array}$ & 784 & 196 & 392 & 392 & 3136 \\
\hline
\end{tabular}

\section{2. 連結制振系建物モデルの定義}

図 1 に, 本論文で扱う連結制振系の単純モデルを示寸. 独立した 2 棟の建物をともに 1 質点とした 2 自由度の平面せん断質点系モデルと して扱い, 一方を主系, 他方を副系と呼ぶ. 主系の質量および剛性を $M, K$, 副系の質量および岡性を $m, k$ とし, 棟間を連結する粘性 ダンパーの減衰係数を $c$ とする. ただし $M \geq m$ とする. なお, ここ では建物の構造減衰は考慮しない. 副系に対する主系の質量比 $M / m$ を $\mu(\geq 1)$, 剛性比 $K / k$ を $\kappa$ とし, 質量比と剛性比の積 $M K / m k$ を $\mu \kappa$ で表す.

本論文では, 複素固有值解析による固有円振動数, 減衰定数, 固有 值, 固有モードを単に固有円振動数, 減衰定数, 固有值および固有モ ードと呼ぶ. 連結制振系の振動特性を把握するには連結ダンパー容量 の増加に伴う減衰定数の特性を明らかにする必要がある. 連結制振系 の単純モデルにおいて, 連結ダンパーの減衰係数に対する全体系の減 衰定数の変動の様相は, 2 棟の建物の質量比および剛性比によって異 なる.

\section{3. 連結ダンパーの減衰係数の増加に伴う減衰定数および固有振動特 性の変動}

3. 1 固有値と固有円振動数 - 減衰定数の関係と重複点の定義
本節では，4節以降で述べる質量比と剛性比を軸とする平面におけ る領域分割の準備として,いくつかの代表的な建物モデルに対して連 結ダンパー容量を増加させたときの数值解析を行い, 減衰定数 $h$, 固 有円振動数 $\omega$ およびそれに対応する固有值の変動, 固有モードにつ いて考察する. 解析モデルの諸元を表 1 に，解析モデルの概要を図 2 に示す. 前述のように建物の構造減衰は考慮しない. なお， $h$ および $\omega$ の值は, 複素固有值解析により導出された 4 つの固有值 $\lambda_{k}(k=1,2,3,4)$ を用い, 次のように算出する.

$$
\begin{aligned}
& \lambda_{i}, \lambda_{j}=-h^{(r)} \omega^{(r)} \pm \omega^{(r)} \sqrt{\left\{h^{(r)}\right\}^{2}-1} \\
& \lambda_{i} \lambda_{j}=\left\{\omega^{(r)}\right\}^{2}, \quad \lambda_{i}+\lambda_{j}=-2 h^{(r)} \omega^{(r)} \\
& \therefore \quad \omega^{(r)}=\sqrt{\lambda_{i} \lambda_{j}} \quad, \quad h^{(r)}=-\left(\lambda_{i}+\lambda_{j}\right) /\left(2 \sqrt{\lambda_{i} \lambda_{j}}\right)
\end{aligned}
$$

ここで $r$ は次数, $\lambda_{i}, \lambda_{j}$ は対 (減衰振動域では共役を意味し, $i=1, j=2$ が $r=1$ に, $i=3, j=4$ が $r=2$ に対応）となる固有值である. (3a,b)式によ り，過減衰域の $h$ および $\omega$ も減衰振動域と同様に定義する ${ }^{26)}$.

連結ダンパーの減衰係数 $c$ をパラメターとして変動させたときの固 有值, 減衰定数, 固有円振動数の変動を, モデルI, 基本モデル $(\mu \kappa=1)$, モデル II , III の場合について図 3 に示す. 固有值のグラフにおいて, あるcの值のときに, 異なる 4 つの複素固有值の実部が等しくなる点 （ $\operatorname{Re}\left[\lambda_{k}\right]=$ const.） あるいは虚部の絶対值が等しくなる点 $\left(\mid \operatorname{Im}\left[\lambda_{k}\right]=\right.$ const. $)$ ，またはその両方が成立する点が存在する場合が ある、この点を「重複点」と呼ぶこととする。モデルIでは実部のみ が，モデルIIでは虚部のみが，基本モデル $(\mu \kappa=1)$ では両方に重複 点が存在している. また, 非単調に変動する側の減衰定数が極值をと る点, および単調に増加する側の減衰定数が臨界減衰となる点の 2 点を境界として, グラフを 3 つの区間に分け, ダンパー減衰係数の小 さい方からそれぞれ区間 $A$ ，区間B，区間Cとする．区間 $\mathrm{A}, \mathrm{B}$ は減衰振 動域，区間Cは過減衰域である.

なお, 重複点に相当する点が過減衰域にある場合には, 重複点の定 義を「4 つの実固有值が, 2 組の重複固有值となる」とする (Appendix 1 参照). またこのとき, 単調に増加する側の減衰定数が臨界減衰と なる点および非単調に変動する側の減衰定数が極值をとる点の 2 点

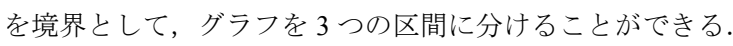

図 4 は, 各区間のある点における固有モードを示している. 連結系 の固有ベクトルは一般に複素ベクトルとなるため, 図 4 では固有べク トルの主系 (右側) と副系（左側）の成分のそれぞれを，最大の成分 の值が 1 となるように正規化し、複素平面上に表示している.

以下では, 基本モデル $(\mu \kappa=1$ : 詳細については後述) の場合とそ れ以外 $(\mu \kappa \neq 1)$ の場合に分けて考察する.

\section{$3.2 \mu \kappa=1$ の場合}

$\mu \kappa=1$ の場合, 図 3(b)より, 区間 A, B の境界と重複点とが一致す ると予想される. 各区間における減衰定数, 固有円振動数および固有 值は以下の性質を示す.

区間 A : $h^{(1)}=h^{(2)}(<1), \omega^{(1)} \neq \omega^{(2)}: 1$ 次，2 次ともに複素固有值 区間 B : $h^{(1)} \neq h^{(2)}(<1), \omega^{(1)}=\omega^{(2)}: 1$ 次, 2 次ともに複素固有值 区間 $\left.\mathrm{C}: h^{(1)}(>1) \neq h^{(2)}<1\right), \omega^{(1)}=\omega^{(2)}: 1$ 次が実固有值，2次が 複素固有值

固有值は，区間 $\mathrm{A} ， \mathrm{~B}$ では異なる 2 組の複素固有值となるが，重複 点（区間 $\mathrm{A}, \mathrm{B}$ の境界）においてそれらは等しい值の組となり, 臨界 減衰点（区間 B，C の境界）において 1 組の固有值の実部が 2 つの異 なる值となり，それに対応する固有值の虚部が 0 となる. 

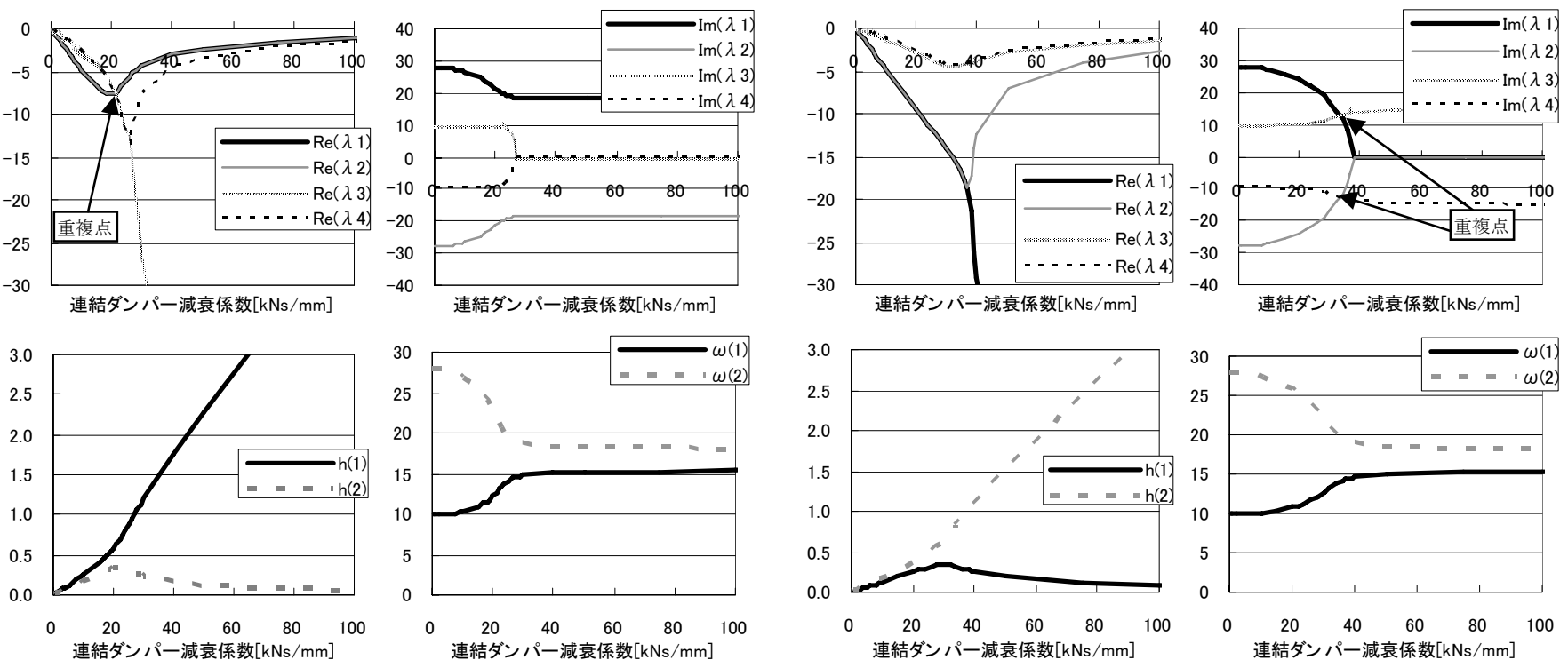

(a)モデル I $(\mu \kappa=0.5)$
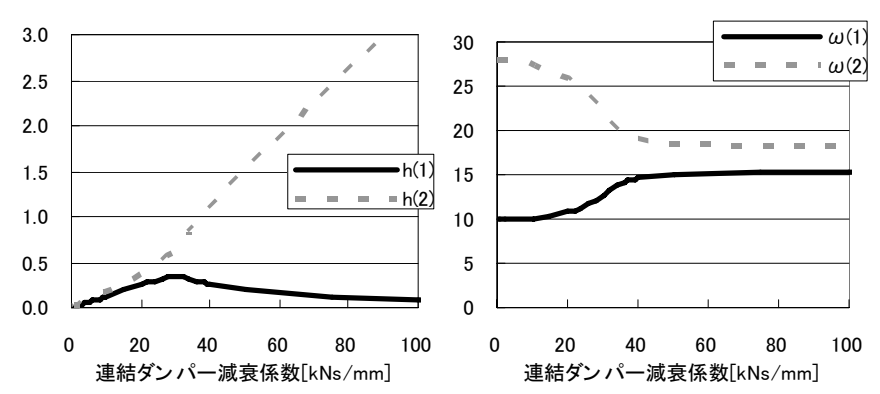

(c) モデル II $(\mu \kappa=2.0)$
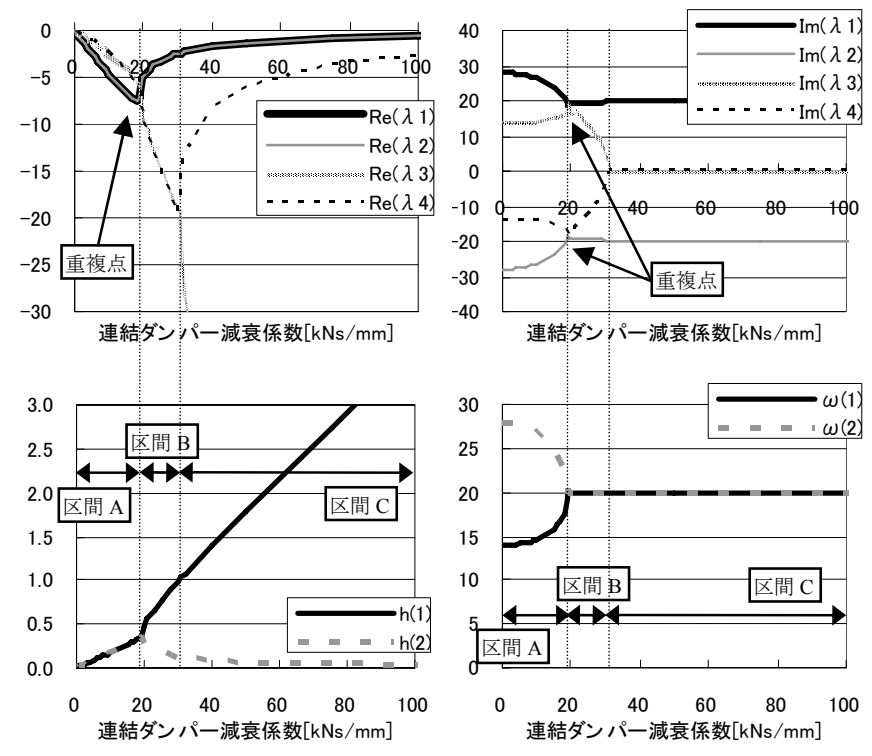

(b) 基本モデル $(\mu \kappa=1.0)$
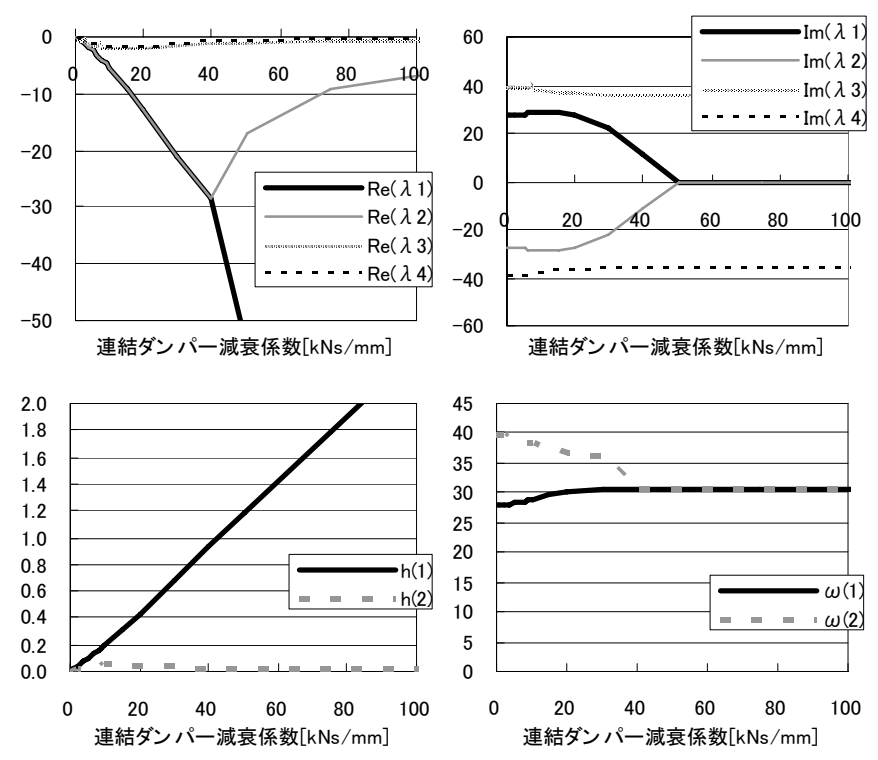

(d) モデルIII $(\mu \kappa=8.0)$

図 3 各モデルにおうける固有值・減衰定数・固有円振動数の変動 $($ 左上 : $\operatorname{Re}[\lambda](\mathrm{rad} / \mathrm{s})$, 右上 : $\operatorname{Im}[\lambda](\mathrm{rad} / \mathrm{s})$, 左下 : $h$, 右下 : $\omega(\mathrm{rad} / \mathrm{s}))$

減衰定数は, 区間 A では 1 次と 2 次が等しく, $h<1$ の領域内の重 複点を境に 2 つの異なる值となり (区間 B), その後一方は 0 に収束 し，もう一方は増大しやがて過減衰となる（区間 C).

固有円振動数は, 区間 A では異なる 2 つの值がダンパー減衰係数 の増加に伴って近接していき, 重複点を越え区間 $\mathrm{B}, \mathrm{C}$ では両者は等 しい值となる. また, この区間 B, C での固有円振動数は, 2 棟を剛 結したモデルの固有円振動数に等しい.

重複点における分岐の変化勾配はのであるものと見られ,ダンパー 減衰係数のわずかな変動に対して, 固有值, 減衰定数, 固有円振動数 の值は大きく変動する.

図 4(b)より, 固有モードは以下の性質を示す. 区間 A において, 従属して動く側の建物がそれぞれ 1 次と 2 次とで共役な複素固有モー ドをとり, その絶対值は 1 より小さい. 区間 B において, 従属して 動く側の建物が 1 次と 2 次とで異なる複素固有モードをとるが, それ らの絶対值はともに 1 となる. 区間 $\mathrm{C}$ において, 過減衰である 1 次
は異なる $2 つ の$ 実固有モードであり,それらの位相は $\pi$ ずれている. 減衰定数が 0 に収束する 2 次は従属して動く側の建物が絶対值 1 の複 素固有モードをとり, その位相はダンパー減衰係数の増加に伴って卓 越して動く側の建物のモードの位相に近接していく.このようなモー ドをとることから, ダンパー減衰係数の増加に伴う減衰定数の変化が 重複点で分岐した後, 1 次が増大, 2 次が減少するものと考えられる.

\section{$3.3 \mu \kappa \neq 1$ の場合}

$\mu \kappa \neq 1$ の場合, 図 3(a), (c) より, 区間 A, B の境界と重複点とは一 致しない. 重複点において, モデル I $(\mu \kappa=0.5)$ の場合では異なる 4 つの複素固有值の実部が等しく, モデル II $(\mu \kappa=2.0)$ の場合では 異なる 4 つの複素固有值の虚部の絶対值が等しい. また図 3(d)より, モデルIII $(\mu \kappa=8.0)$ の場合では重複点は存在しない.

重複点の誘導については 4 節で触れる. また, 連結ダンパー容量を 増加させたときの減衰定数と固有円振動数の性質については 5,6 節 で詳述する. 

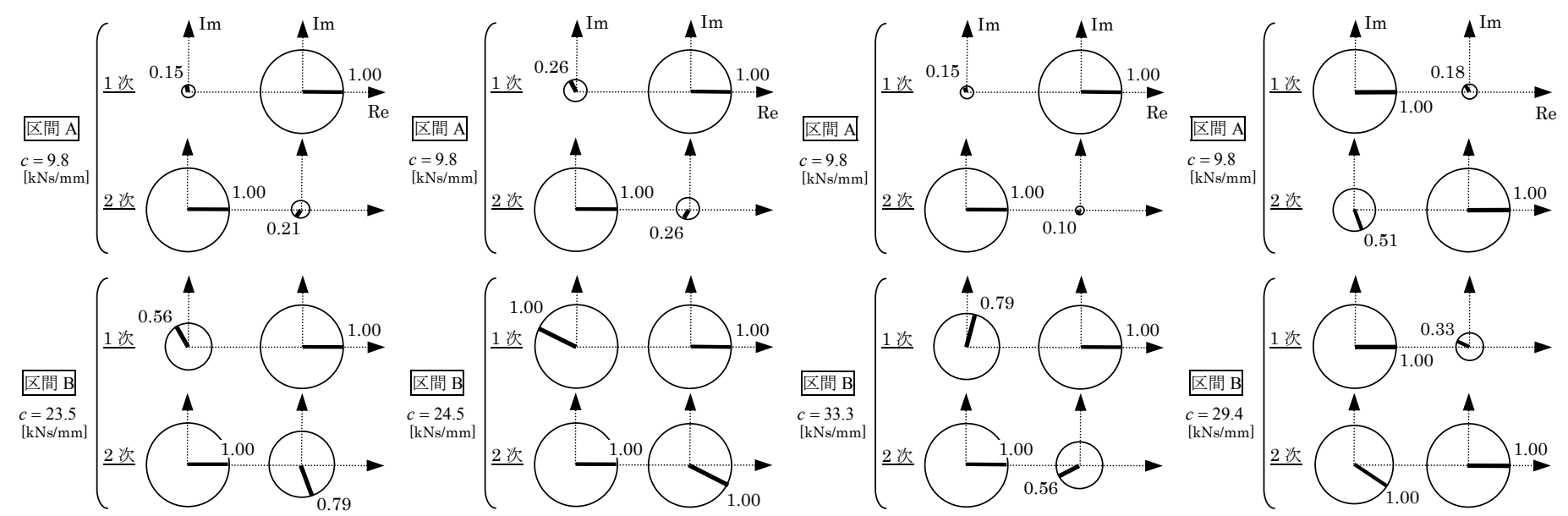

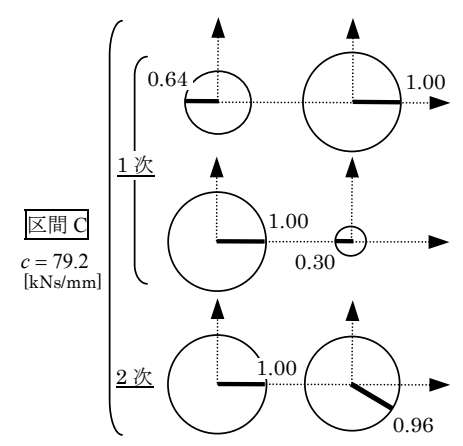

(a) モデル I $(\mu \kappa=0.5)$

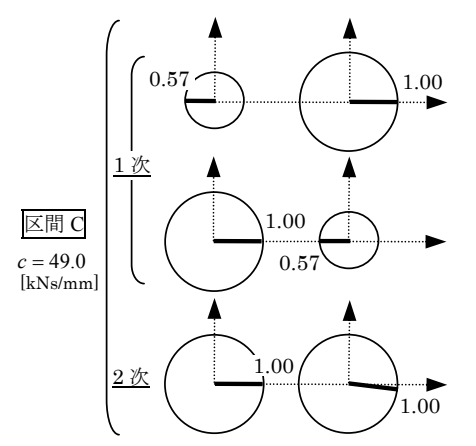

(b) 基本モデル $(\mu \kappa=1.0)$

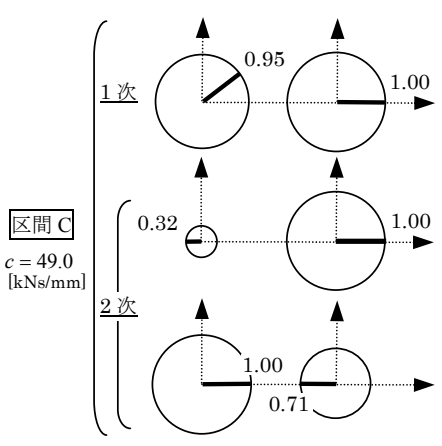

(c) モデル II $(\mu \kappa=2.0)$

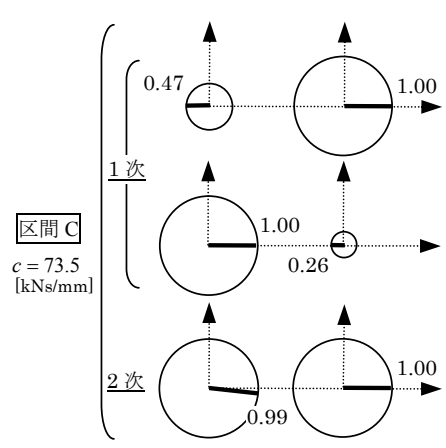

(d) モデルIII $(\mu \kappa=8.0)$

図 4 各区間のある点における固有モード（右：主系，左 : 副系, 数字は絶対值)

\section{4. 重複点の条件式}

\section{1 共通事項}

3 節で導入した 2 棟連結建物モデルについて, 図 3 のグラフにおけ る重複点, またはそれに対応する点を特徴付ける条件式について考え る. それぞれの建物モデルの質量比および岡性比と, 連結ダンパーの 減衰係数, 連結モデルの減衰定数および固有円振動数間の関係を示す.

図 1 のモデルにおける自由振動の支配式は, 固有值 $\lambda$ を用いて (4) 式のように表される.

$$
\begin{aligned}
& \left|\lambda^{2}\left[\begin{array}{cc}
m & 0 \\
0 & M
\end{array}\right]+\lambda\left[\begin{array}{cc}
c & -c \\
-c & c
\end{array}\right]+\left[\begin{array}{cc}
k & 0 \\
0 & K
\end{array}\right]\right|=0 \\
& \therefore \operatorname{det}\left[\begin{array}{cc}
m \lambda^{2}+c \lambda+k & -c \lambda \\
-c \lambda & M \lambda^{2}+c \lambda+K
\end{array}\right]=0
\end{aligned}
$$

この行列式を計算すると, 次の 4 次方程式となる.

$$
M m \lambda^{4}+(M+m) c \lambda^{3}+(M k+m K) \lambda^{2}+(K+k) c \lambda+K k=0
$$

(5)式（実数係数）の 4 つの解をそれぞれ $\lambda_{1}, \lambda_{2}, \lambda_{3}, \lambda_{4}$ とおくと, 4 次方程式の解と係数の関係より以下の式が成り立つ.

$$
\begin{aligned}
& \lambda_{1}+\lambda_{2}+\lambda_{3}+\lambda_{4}=-\frac{(M+m) c}{M m} \\
& \lambda_{1} \lambda_{2}+\lambda_{2} \lambda_{3}+\lambda_{3} \lambda_{4}+\lambda_{4} \lambda_{1}+\lambda_{1} \lambda_{3}+\lambda_{2} \lambda_{4}=\frac{M k+m K}{M m} \\
& \lambda_{1} \lambda_{2} \lambda_{3}+\lambda_{2} \lambda_{3} \lambda_{4}+\lambda_{3} \lambda_{4} \lambda_{1}+\lambda_{4} \lambda_{1} \lambda_{2}=-\frac{(K+k) c}{M m} \\
& \lambda_{1} \lambda_{2} \lambda_{3} \lambda_{4}=\frac{K k}{M m}
\end{aligned}
$$

ここで, 異なる 4 つの複素固有值を以下のようにおく.

$$
\begin{aligned}
& \lambda_{1,2}=\operatorname{Re}[\alpha] \pm \mathrm{i} \operatorname{Im}[\alpha] \quad(\mathrm{i}: \text { 虚数単位 }) \\
& \lambda_{3,4}=\operatorname{Re}[\beta] \pm \mathrm{i} \operatorname{Im}[\beta]
\end{aligned}
$$

(7a,b)式を用いて，(6a-d)式は以下のように書き換えられる.

$$
\begin{gathered}
2(\operatorname{Re}[\alpha]+\operatorname{Re}[\beta])=-\frac{(M+m) c}{M m} \\
\{\operatorname{Re}[\alpha]\}^{2}+\{\operatorname{Im}[\alpha]\}^{2}+\{\operatorname{Re}[\beta]\}^{2}+\{\operatorname{Im}[\beta]\}^{2}+4 \operatorname{Re}[\alpha] \operatorname{Re}[\beta] \\
=\frac{M k+m K}{M m} \\
2\left\{\operatorname{Re}[\alpha]\left(\{\operatorname{Re}[\beta]\}^{2}+\{\operatorname{Im}[\beta]\}^{2}\right)+\operatorname{Re}[\beta]\left(\{\operatorname{Re}[\alpha]\}^{2}+\{\operatorname{Im}[\alpha]\}^{2}\right)\right\} \\
=-\frac{(K+k) c}{M m} \\
\left(\{\operatorname{Re}[\alpha]\}^{2}+\{\operatorname{Im}[\alpha]\}^{2}\right)\left(\{\operatorname{Re}[\beta]\}^{2}+\{\operatorname{Im}[\beta]\}^{2}\right)=\frac{K k}{M m}
\end{gathered}
$$

\section{4. $2 \mu \kappa<1$ の場合}

図 3(a)のグラフにおける重複点での条件を考える（モデル I ）。重 複点において，4 つの複素固有值は実部がいずれも等しいことから， $\operatorname{Re}[\alpha]=\operatorname{Re}[\beta]$ である. ここで, $\operatorname{Re}[\alpha]=\operatorname{Re}[\beta]=\operatorname{Re}[\lambda]$ とおき直すと， (8a-d)式は以下のように書き換えられる.

$$
\begin{aligned}
& 4 \operatorname{Re}[\lambda]=-\frac{(M+m) c}{M m} \\
& 6\{\operatorname{Re}[\lambda]\}^{2}+\{\operatorname{Im}[\alpha]\}^{2}+\{\operatorname{Im}[\beta]\}^{2}=\frac{M k+m K}{M m} \\
& 2 \operatorname{Re}[\lambda]\left(2\{\operatorname{Re}[\lambda]\}^{2}+\{\operatorname{Im}[\alpha]\}^{2}+\{\operatorname{Im}[\beta]\}^{2}\right)=-\frac{(K+k) c}{M m} \\
& \left(\{\operatorname{Re}[\lambda]\}^{2}+\{\operatorname{Im}[\alpha]\}^{2}\right)\left(\{\operatorname{Re}[\lambda]\}^{2}+\{\operatorname{Im}[\beta]\}^{2}\right)=\frac{K k}{M m}
\end{aligned}
$$

(9a-d)式を $c$ について解くと, 重複点におけるダンパー減衰係数 $c$ は 以下の式で表すことができる.

$$
\begin{aligned}
c=2 \frac{M-m}{M+m} \sqrt{\frac{M m}{M^{2}-m^{2}}(M k-m K)} & =2 \frac{M-m}{M+m} \sqrt{\frac{M^{2} \cdot m k-m^{2} \cdot M K}{M^{2}-m^{2}}} \\
& =2 \frac{M-m}{M+m} \sqrt{\frac{m^{3} k \mu^{2}}{M^{2}-m^{2}}\{1-(\kappa / \mu)\}}
\end{aligned}
$$


このとき, 重複点における減衰定数 $h$ および固有円振動数 $\omega$ はそれ ぞれ以下の式で表すことができる.

$$
\begin{aligned}
h^{(1)}, h^{(2)} & =\frac{1}{2} \sqrt{\frac{(M-m)(M k-m K)}{M m(K+k) \pm \sqrt{M m(m k-M K)(M k-m K)}}} \\
& =\frac{1}{2} \sqrt{\frac{(M-m) M k\{1-(\kappa / \mu)\}}{M m(K+k) \pm M m k \sqrt{(1-\mu \kappa)\{1-(\kappa / \mu)}\}}} \\
\omega^{(1)}, \omega^{(2)} & =\sqrt{\frac{1}{M+m}\left(K+k \pm \sqrt{\frac{(m k-M K)(M k-m K)}{M m}}\right)} \\
& =\sqrt{\frac{1}{M+m}(K+k \pm k \sqrt{(1-\mu \kappa)\{1-(\kappa / \mu)\}})}
\end{aligned}
$$

複号において, 1 次が-、2 次が+に対応する. (11),(12)式から， $\mu \kappa=1$ と $\mu=\kappa$ が領域を分ける関係式であることが理解され，(11),(12)式の 根号内の表現から， $\mu \kappa<1$ の場合には. $\mu>\kappa$ となる必要がある（後 述の図 5 の領域 $\mathrm{I}$ に対応). また, (11)式から, 1 次の減衰定数は 2 次 よりも大きいことがわかる.

\section{3 基本モデル $(\mu \kappa=1)$ の場合}

図 3(b)のグラフにおける重複点での条件を考える. 重複点において, 4 つの複素固有值は実部および虚部の絶対值がいずれも等しいこと から， $\operatorname{Re}[\alpha]=\operatorname{Re}[\beta]$ かつ $\operatorname{Im}[\alpha]=\operatorname{Im}[\beta]$ である.ここで，それぞれを $\operatorname{Re}[\alpha]=\operatorname{Re}[\beta]=\operatorname{Re}[\lambda], \quad \operatorname{Im}[\alpha]=\operatorname{Im}[\beta]=\operatorname{Im}[\lambda]$ とおき直すと， (8a-d) 式は以下のように書き換えられる。

$$
\begin{aligned}
& \lambda_{1}+\lambda_{2}+\lambda_{3}+\lambda_{4}=4 \operatorname{Re}[\lambda]=-\frac{(M+m) c}{M m} \\
& \lambda_{1} \lambda_{2}+\lambda_{2} \lambda_{3}+\lambda_{3} \lambda_{4}+\lambda_{4} \lambda_{1}+\lambda_{1} \lambda_{3}+\lambda_{2} \lambda_{4} \\
&=6\{\operatorname{Re}[\lambda]\}^{2}+2\{\operatorname{Im}[\lambda]\}^{2}=\frac{M k+m K}{M m}
\end{aligned}
$$

$\lambda_{1} \lambda_{2} \lambda_{3}+\lambda_{2} \lambda_{3} \lambda_{4}+\lambda_{3} \lambda_{4} \lambda_{1}+\lambda_{4} \lambda_{1} \lambda_{2}$

$$
=4 \operatorname{Re}[\lambda]\left(\{\operatorname{Re}[\lambda]\}^{2}+\{\operatorname{Im}[\lambda]\}^{2}\right)=-\frac{(K+k) c}{M m}
$$

$\lambda_{1} \lambda_{2} \lambda_{3} \lambda_{4}=\left(\{\operatorname{Re}[\lambda]\}^{2}+\{\operatorname{Im}[\lambda]\}^{2}\right)^{2}=\frac{K k}{M m}$

さらに, $\mu \kappa=1$ であるので,

$$
\mu \kappa=\frac{M K}{m k}=1 \Leftrightarrow M K=m k
$$

(13a-d)式を $c$ について解き(14)式の条件を用いて整理すると, 重複点 におけるダンパー減衰係数 $c$ は以下の式で表すことができる.

$$
c=2 \frac{M-m}{M+m} \sqrt{M K}=2 \frac{M-m}{M+m} \sqrt{m k}
$$

このとき, 重複点における減衰定数 $h$ および固有円振動数 $\omega$ は, そ れぞれ以下の式で表すことができる.

$$
\begin{aligned}
& h=-\frac{\operatorname{Re}[\lambda]}{\sqrt{\{\operatorname{Re}[\lambda]\}^{2}+\{\operatorname{Im}[\lambda]\}^{2}}}=\frac{1}{2} \sqrt{\frac{\left(M^{2}-m^{2}\right)(k-K)}{M m(K+k)}}=\frac{1-\kappa}{2 \sqrt{\kappa}} \\
& \omega=\sqrt{\{\operatorname{Re}[\lambda]\}^{2}+\{\operatorname{Im}[\lambda]\}^{2}}=\sqrt{\frac{K+k}{M+m}}
\end{aligned}
$$

(16), (17)式の最終項は, 固有值が実数であるか複素数であるかにかか わらず成り立つ式であるが, 第 2 項から第 3 項への変形は重複点にお ける固有值が複素数, 寸なわち重複点における減衰定数が 1 以下の場 合にのみ成り立つ。

重複点における減衰定数が 1 となる条件を(16)式より整理すると, 以下の式となる.

$$
h=1 \Leftrightarrow \kappa=-\mu^{2}+5 \mu+5
$$

$$
\therefore \quad \mu=3+2 \sqrt{2} \quad(\because \mu \kappa=1)
$$

境界 $\mu \kappa=1$ 上では， $\mu$ の值の増加に伴って重複点における減衰定数 は増加する傾向にあり (図 8,9 参照)，(18)式より $\mu>3+2 \sqrt{2}$ におい て $h>1$ となる. この範囲での重複点における実固有值は完全に重複 寸るのではなく, 2 組の重複した実固有值に分けられることになる (Appendix 1 参照).

また $\mu \kappa \neq 1$ の場合, 重複点における非単調に変動する減衰定数が 過減衰となる範囲は, 本研究で扱う $\mu(\geq 1)$ および $\kappa(>0)$ の值の領域 に存在しないため，(18)式を境界として固有值の性質が分かれるこ とはない。

\section{4. $4 \mu \kappa>1$ の場合}

図 3(c)のグラフにおける重複点での条件を考える. 重複点において, 4 つの複素固有值は虚部の絶対值がいずれも等しいことから, $\operatorname{Im}[\alpha]=\operatorname{Im}[\beta]$ である. ここで, $\operatorname{Im}[\alpha]=\operatorname{Im}[\beta]=\operatorname{Im}[\lambda]$ とおき直すと， (8a-d)式は以下のように書き換えられる.

$$
\begin{aligned}
& 2(\operatorname{Re}[\alpha]+\operatorname{Re}[\beta])=-\frac{(M+m) c}{M m} \\
& (\operatorname{Re}[\alpha]+\operatorname{Re}[\beta])^{2}+2\left(\operatorname{Re}[\alpha] \operatorname{Re}[\beta]+\{\operatorname{Im}[\lambda]\}^{2}\right)=\frac{M k+m K}{M m} \\
& 2(\operatorname{Re}[\alpha]+\operatorname{Re}[\beta])\left(\operatorname{Re}[\alpha] \operatorname{Re}[\beta]+\{\operatorname{Im}[\lambda]\}^{2}\right)=-\frac{(K+k) c}{M m} \\
& \left(\{\operatorname{Re}[\alpha]\}^{2}+\{\operatorname{Im}[\lambda]\}^{2}\right)\left(\{\operatorname{Re}[\beta]\}^{2}+\{\operatorname{Im}[\lambda]\}^{2}\right)=\frac{K k}{M m}
\end{aligned}
$$

(19a-d)式を $c$ について解くと, 重複点におけるダンパー減衰係数 $c$ は, $\mu \kappa<1$ の場合と同様に(10)式で表すことができる（モデル II ）。 ただ ᄂ,

$$
M k-m K<0 \Leftrightarrow \frac{M}{m}<\frac{K}{k} \Leftrightarrow \mu<\kappa
$$

となるような領域では(10)式は実数解をもたない. よって， $\mu<\kappa の$ 領域（モデルIII）において重複点は存在しない.

\section{5. 連結ダンパー容量の増加に伴う固有振動数と減衰定数の変動特性 による分類}

図 5 は, 4 節での検討に基づく $\mu$ と $\kappa$ による減衰定数の変動の様相 の領域分けである. $\mu \geq 1$ の範囲において $\mu \kappa=1, \mu=\kappa$ を境界と して, 減衰定数の変動の様相をそれぞれ異なる 3 つの領域に分けるこ とができる. 連結ダンパーの減衰係数に対する減衰定数の変動の様相 の違いを図 6 に示す. 領域 I, III では, 連結ダンパーの減衰係数の増 加に伴って 1 次減衰定数は単調に増加するが, 2 次減衰定数はある点 で極值をとったのち 0 に収束する。これに対し領域 II では，2 次減衰 定数が単調増加し 1 次減衰定数が非単調に変動する. また, 境界上は 特別な場合に相当し, 各領域とは異なる変動の様相を呈する. 境界 $\mu \kappa=1$ 上では, 連結ダンパーの減衰係数の特別な值の点まで 1 次およ び 2 次の減衰定数は等しく, その点を境として異なる 2 つ值に分岐 し, 一方が増加, 一方が 0 に収束する. 境界 $\mu=\kappa$ 上では, 連結ダン パーの減衰係数にかかわらず 1 次, 2 次ともに減衰定数が 0 であり, この場合連結による制振効果は得られない. 連結ダンパー減衰係数 $c$ が無限大となったとき, 減衰定数のうちの 1 つはゼロに収束すること の証明を Appendix 2 に示す.

領域 I , II には, アウトフレーム連結制振モデル ${ }^{7,8)}$ や低層建物と 高層建物の連結モデル等が該当する. 領域而には, 鉄筋コンクリート 構造 (重くて剛) と鉄骨構造 (軽くて柔) の連結モデル等が該当する. 
尚、序文でも述べたように, 楊ら ${ }^{10}$ は質量比と固有振動数比を軸 とする平面において類似の領域分割を行っているが, そこでは定点理 論に基づき, 定点における伝達率の特性に関する領域分割を行ってお り, 連結ダンパー容量の増加に対する減衰定数や固有振動数の変動特 性に関寸る分類を行っている本論文とは目的が異なる。また, 本論文 での記号を用いると, 楊らの領域境界は $\mu=\kappa$ と $\kappa=1 /(2 \mu+1)$ であり， 連結制振モデルにおいて自明の境界である $\mu=\kappa$ は同じであるもの の，他方のものは本論文の $\kappa=1 / \mu \quad(\mu \kappa=1)$ とは異なる.

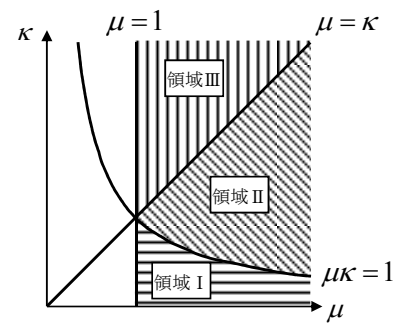

図 $5 \mu$ と $\kappa$ による領域分類
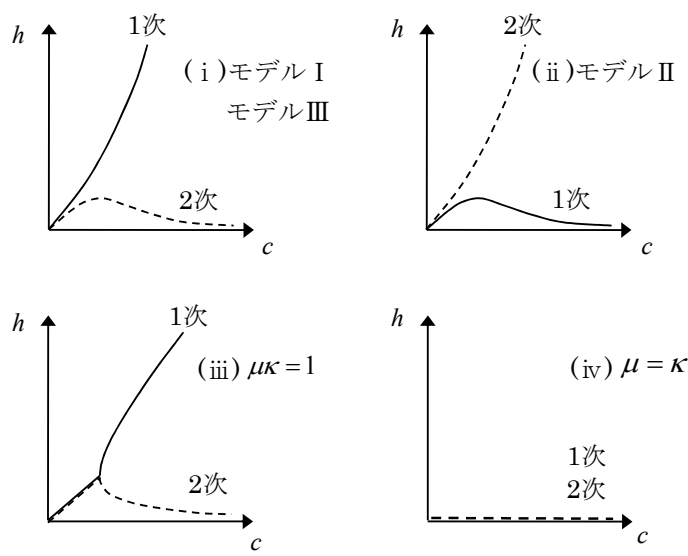

図 6 モデルごとの減衰定数の変動の様相

\section{6. 基本モデル $(\mu \kappa=1)$ における減衰定数と固有円振動数の性質}

\section{1 準備計算}

本節では, 3 節と 4 節で示された基本モデル $(\mu \kappa=1)$ における減 衰定数と固有円振動数の性質について, 詳細な証明を交えた説明を行 う.ここでは, $M>m>0, k>K>0, c>0$ とする. 減衰振動（臨界 減衰以下), 寸なわち, 全ての固有值 $\lambda_{1}, \lambda_{2}, \lambda_{3}, \lambda_{4}$ が複素数の場合を考 える. 過減衰モードを含む場合は付録に示寸．このとき，代数方程式 の性質から， $\lambda_{1}, \lambda_{2}, \lambda_{3}, \lambda_{4}$ は 2 組の共約なぺアに分けることができる. そこで, $\lambda_{1}=\lambda_{2}{ }^{*}, \lambda_{3}=\lambda_{4}{ }^{*}$ とする. このとき, 固有值と固有円振動数, 減衰定数の関係を用いると, 次の関係が成立する.

$$
\begin{aligned}
& \lambda_{1}=-h^{(1)} \omega^{(1)}+\omega^{(1)} \sqrt{1-h^{(1) 2}} \mathrm{i}, \lambda_{2}=-h^{(1)} \omega^{(1)}-\omega^{(1)} \sqrt{1-h^{(1) 2}} \mathrm{i} \\
& \lambda_{3}=-h^{(2)} \omega^{(2)}+\omega^{(2)} \sqrt{1-h^{(2) 2}} \mathrm{i}, \lambda_{4}=-h^{(2)} \omega^{(2)}-\omega^{(2)} \sqrt{1-h^{(2) 2}} \mathrm{i}
\end{aligned}
$$

したがって

$$
\begin{aligned}
& \lambda_{1} \lambda_{2}=\left(\omega^{(1)}\right)^{2}, \quad \lambda_{3} \lambda_{4}=\left(\omega^{(2)}\right)^{2} \\
& \lambda_{1}+\lambda_{2}=-2 h^{(1)} \omega^{(1)}, \quad \lambda_{3}+\lambda_{4}=-2 h^{(2)} \omega^{(2)}
\end{aligned}
$$

ここで簡単のために, 次の表記を導入する.

$\Omega^{(r)} \equiv\left(\omega^{(r)}\right)^{2}, \quad Z^{(r)}=2 h^{(r)} \omega^{(r)}$

(22a-d)式を(6)式に代入し，(23a,b)式の表記を用いると，以下を得る。

$$
\begin{aligned}
& Z^{(1)}+Z^{(2)}=\frac{M+m}{M m} c, \Omega^{(1)}+\Omega^{(2)}+Z^{(1)} Z^{(2)}=\frac{M k+m K}{M m} \\
& \Omega^{(1)} Z^{(2)}+\Omega^{(2)} Z^{(1)}=\frac{K+k}{M m} c, \Omega^{(1)} \Omega^{(2)}=\frac{K k}{M m}
\end{aligned}
$$

(24a-d)式は, 4 つ正の実数 $Z^{(1)}, Z^{(2)}, \Omega^{(1)}, \Omega^{(2)}$ を未知数とする非線形 連立方程式である。 あるいは，4 つの正の実数 $h^{(1)}, h^{(2)}, \omega^{(1)}, \omega^{(2)}$ を末 知数とする非線形連立方程式であるともいえる.

$(24 \mathrm{a}-\mathrm{d})$ 式から $Z^{(1)}$ と $Z^{(2)}$ を消去することを考える. (24a, c)式より, 次式が得られる.

$$
\left(1-\frac{\Omega^{(1)}}{\Omega^{(2)}}\right) Z^{(1)}=\left(\frac{1}{\Omega^{(2)}} \frac{K+k}{M m}-\frac{\Omega^{(1)}}{\Omega^{(2)}} \frac{M+m}{M m}\right) c
$$

6.2 基本モデル $(\mu \kappa=1)$ において $c$ がある值以上で 2 つの固有円振 動数 $\omega$ が一致して定数となる証明（図 $7($ (a) )

今， $\Omega^{(1)} \neq \Omega^{(2)}$ であれば，(25)式と(24a)式より次式が得られる.

$$
\begin{aligned}
Z^{(1)} & =\frac{\frac{1}{\Omega^{(2)}} \frac{K+k}{M m}-\frac{\Omega^{(1)}}{\Omega^{(2)}} \frac{M+m}{M m}}{1-\frac{\Omega^{(1)}}{\Omega^{(2)}}} c=\frac{(K+k)-\Omega^{(1)}(M+m)}{M m\left(\Omega^{(2)}-\Omega^{(1)}\right)} c \\
Z^{(2)} & =\frac{M+m}{M m} c-\frac{\frac{1}{\Omega^{(2)}} \frac{K+k}{M m}-\frac{\Omega^{(1)}}{\Omega^{(2)}} \frac{M+m}{M m}}{1-\frac{\Omega^{(1)}}{\Omega^{(2)}}} c=\frac{M+m}{M m} c-\frac{(K+k)-\Omega^{(1)}(M+m)}{M m\left(\Omega^{(2)}-\Omega^{(1)}\right)} c \\
& =\frac{(M+m)\left(\Omega^{(2)}-\Omega^{(1)}\right)}{M m\left(\Omega^{(2)}-\Omega^{(1)}\right)} c-\frac{(K+k)-\Omega^{(1)}(M+m)}{M m\left(\Omega^{(2)}-\Omega^{(1)}\right)} c=\frac{(K+k)-\Omega^{(2)}(M+m)}{M m\left(\Omega^{(2)}-\Omega^{(1)}\right)} c
\end{aligned}
$$

$(26 \mathrm{a}, \mathrm{b})$

すなわち， $Z^{(1)}$ と $Z^{(2)}$ が消去されたことになり， $\Omega^{(1)}$ と $\Omega^{(2)}$ を得る には，(26a,b)式を(24b)式に代入し，それと(24d)式を $\Omega^{(1)} と \Omega^{(2)}$ を末 知数とする非線形連立方程式として解けばよい. しかし，この場合に ついては本節の目的と合致しないので省略する.

一方, もし $\Omega^{(1)}=\Omega^{(2)}$, すなわち $\omega^{(1)}=\omega^{(2)}$ であれば,

$\Omega^{(1)}=\Omega^{(2)} \equiv \Omega$

とし，これを(24a-d)式に代入すると，次式を得る.

$$
\begin{aligned}
& Z^{(1)}+Z^{(2)}=\frac{M+m}{M m} c, 2 \Omega+Z^{(1)} Z^{(2)}=\frac{M k+m K}{M m} \\
& \Omega\left(Z^{(1)}+Z^{(2)}\right)=\frac{K+k}{M m} c, \Omega^{2}=\frac{K k}{M m}
\end{aligned}
$$

(28a)式と(28c)式より，次式が導かれる.

$$
\Omega=\frac{\frac{K+k}{M m} c}{\frac{M+m}{M m} c}=\frac{K+k}{M+m} \Rightarrow \omega^{(1)}=\omega^{(2)}=\sqrt{\frac{K+k}{M+m}}
$$

このとき，次の性質が存在する.

特性 1 : 過減衰モードを含まない連結系において, $\omega^{(1)}=\omega^{(2)}$ で あるときには，その值は連結ダッシュポットの減衰係数 $c$ には無 関係であり，両質点を剛連結したときの固有円振動数に等しい. 次に, (28d)式と(29)式より, $\Omega^{(1)}=\Omega^{(2)}$ となるための必要条件は次 のように表される。

$$
M K-m k=0 \Rightarrow M K=m k \Rightarrow \frac{M K}{m k}=\mu \kappa=1
$$

したがって, 次の性質が存在する.

特性 2 : 過減衰モードを含まない連結系において, $\omega^{(1)}=\omega^{(2)}$ と なるためには， $\mu \kappa=1$ でなければならない.

さらに, $\Omega^{(1)}=\Omega^{(2)}$ の場合に $Z^{(1)}$ と $Z^{(2)}$ が実数となるための条件よ り, 次式が導かれる. 


$$
c \geq \sqrt{\frac{4(M-m)^{2} M K}{(M+m)^{2}}}=\frac{2(M-m)}{(M+m)} \sqrt{M K}=\frac{2(M-m)}{(M+m)} \sqrt{m k}
$$

したがって，次の性質が存在する．

特性 3 : 過減衰モードを含まない連結系において， $\mu \kappa=1$ かつ

$$
c \geq \frac{2(M-m)}{(M+m)} \sqrt{M K}
$$

のとき，以下の関係が成立する.

$$
\omega^{(1)}=\omega^{(2)}=\sqrt{\frac{K+k}{M+m}}
$$

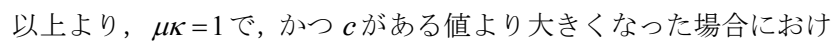
る, 固有円振動数 $\omega$ の重複および定数化現象が証明された.

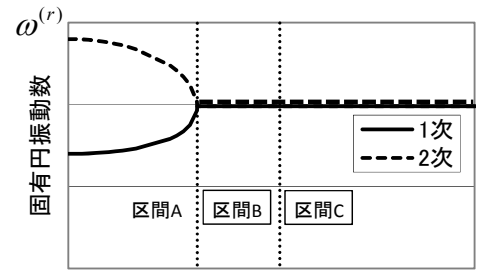

連結ダンパー減衰係数 $c$

(a) (b)

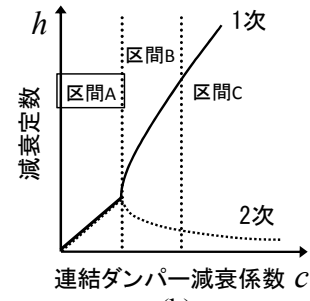

図 7 (a) 固有円振動数 $\omega$ の重複および定数化現象（区間 B, C), (b) 減衰定数の重複現象（区間 A)

\section{3 基本モデル $(\mu \kappa=1)$ において $c$ がある值以下で $2 つ の$ 減衰定数} $h$ が重複する証明（図 $7(\mathrm{~b})$ )

(24a)式と(24c)式から誘導された $(26 a, b)$ 式を再度書き, $\Omega$ と $Z$ の定 義を用いると次式が得られる.

$$
\begin{aligned}
& h^{(1)}=\frac{(K+k)-\Omega^{(1)}(M+m)}{2 \sqrt{\Omega^{(1)}} M m\left(\Omega^{(2)}-\Omega^{(1)}\right)} c=\frac{\frac{K+k}{\sqrt{\Omega^{(1)}}}-\sqrt{\Omega^{(1)}}(M+m)}{2 M m\left(\Omega^{(2)}-\Omega^{(1)}\right)} c \\
& h^{(2)}=\frac{(K+k)-\Omega^{(2)}(M+m)}{2 \sqrt{\Omega^{(2)}} M m\left(\Omega^{(1)}-\Omega^{(2)}\right)} c=\frac{\sqrt{\Omega^{(2)}}(M+m)-\frac{K+k}{\sqrt{\Omega^{(2)}}} c}{2 M m\left(\Omega^{(1)}-\Omega^{(2)}\right)} c
\end{aligned}
$$

両者の差をとり, $\mu \kappa=1$ を代入すると, 両者が一致することを次のよ うに示すことができる.

$$
h^{(1)}-h^{(2)}=\frac{\frac{(K+k) \sqrt{M m}}{\sqrt{K k}}-(M+m)}{2 M m\left(\sqrt{\Omega^{(2)}}-\sqrt{\Omega^{(1)}}\right)} c=\frac{\frac{m}{K}\{(K+k)-(k+K)\}}{2 M m\left(\sqrt{\Omega^{(2)}}-\sqrt{\Omega^{(1)}}\right)} c=0 \text { (35) }
$$

したがって, 次の性質が存在する.

特性 4 : 過減衰でない連結系において, $\mu \kappa=1$ かつ

$$
c<\frac{2(M-m)}{(M+m)} \sqrt{M K}
$$

のとき（重複点以下）, 次式が成立し 2 つの減衰定数は重複する.

$$
h^{(1)}=h^{(2)}
$$

\section{7. 数值例題}

\section{1 減衰定数と固有円振動数の特性}

副系の固有周期に対する主系の固有周期の比を $\tau$ で表す.このとき $\tau=\sqrt{\mu / \kappa}$ である. 質量比と岡性比の平面において, $\tau$ は図 8 に示す ような意味を有する. 質量均衡型モデル, 基本モデル $(\mu \kappa=1)$, 剛 性均衡型モデルの 3 種類について, ここでは $\tau=\sqrt{2}, \tau=2, \tau=\sqrt{10}$ の場合の解析結果を示寸. 解析モデルの諸元を表 $2,3,4$ に示寸.

図 9 は, 固有周期比 $\tau=\sqrt{2}, 2, \sqrt{10}$ のモデルについて, 減衰定数の
変化を, 連結ダンパー減衰係数 $c$ をパラメターとして示したものであ る. 質量均衡型モデルは領域 I ああるため，3 節で解説した通り，連 結ダンパーの減衰係数の増加に伴って 1 次減衰定数は単調に増加す るが, 2 次減衰定数はある点で極值をとったのち 0 に収束する.また, 固有周期比の増加に伴い，1 次と 2 次の減衰定数の原点における勾配 は離れることがわかる。

次に, 基本モデルでは, 固有周期比の増加に伴い, 重複点における 減衰定数は大きくなるといえる，さらに，剛性均衡型モデルは領域 II にあるため, 3 節で解説した通り，連結ダンパーの減衰係数の増加 に伴って 2 次減衰定数は単調に増加するが， 1 次減衰定数はある点で 極值をとったのち 0 に収束する. 寸なわち，1次振動が卓越する場合 には，その減衰定数は，連結ダンパーの減衰係数を増加させても頭打 ちとなるため, 連結ダンパーの減衰係数を決定する際には十分な注意 が必要である. また, 質量均衡型モデルと同様に, 固有周期比の増加 に伴い, 1 次と 2 次の減衰定数の原点における勾配は離れることがわ かる。

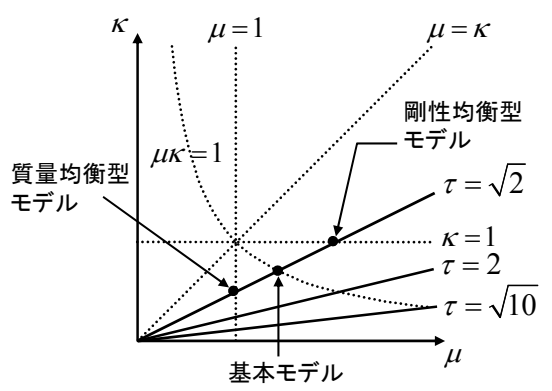

図 8 質量比と岡性比の平面における $\tau$ の意味

\section{2 地震時応答特性との関係}

連結ダンパーによる減衰定数の変化と地震時応答の変化の関係の 一例として，7.1 節で示したモデルの内， $\tau=2$ （表 3）の 3 モデルに ついて，記録地震波（Hachinohe 1968 NS，JMA-Kobe 1995 NS，いず れも地動最大速度を $0.5 \mathrm{~m} / \mathrm{s}$ となるように規準化）を作用させた場合 の主系と副系の最大変位の変化を図 10 に示す。この 3 モデルにおい て副系は同一であり，主系は固有周期が同一である。応答解析には， Newmark- $\beta$ 法に基づく時刻歴応答解析を用いた。 また，両系とも構 造減衰はゼロとした．図中には減衰定数の变化もあわせて示す．

図 10 より, 以下のことが観察される.

表 2 解析モデル諸元 $(\tau=\sqrt{2})$

\begin{tabular}{|c|c|c|c|c|}
\hline \multirow{2}{*}{ モデル } & 副系 & \multicolumn{4}{|c|}{ 主系 } \\
\cline { 3 - 5 } & & 質量均衡型 & 基本 & 剛性均衡型 \\
\hline \hline 質量 $[\mathrm{t}]$ & 300 & $300(\mu=1)$ & $424(\mu=\sqrt{2})$ & $600(\mu=2)$ \\
\hline 剛性 $[\mathrm{kN} / \mathrm{mm}]$ & 294 & $147(\kappa=0.5)$ & $208(\kappa=1 / \sqrt{2})$ & $294(\kappa=1)$ \\
\hline
\end{tabular}

表 3 解析モデル諸元 $(\tau=2)$

\begin{tabular}{|c|c|c|c|c|}
\hline \multirow{2}{*}{ モデル } & 副系 & \multicolumn{4}{|c|}{ 主系 } \\
\cline { 3 - 5 } & & 質量均衡型 & 基本 & 剛性均衡型 \\
\hline \hline 質量 $[\mathrm{t}]$ & 300 & $300(\mu=1)$ & $600(\mu=2)$ & $1200(\mu=4)$ \\
\hline 剛性 $[\mathrm{kN} / \mathrm{mm}]$ & 294 & $73.5(\kappa=0.25)$ & $147(\kappa=0.5)$ & $294(\kappa=1)$ \\
\hline
\end{tabular}

表 4 解析モデル諸元 $(\tau=\sqrt{10})$

\begin{tabular}{|c|c|c|c|c|}
\hline \multirow{2}{*}{ モデル } & \multirow{2}{*}{ 副系 } & \multicolumn{4}{|c|}{ 主系 } \\
\cline { 3 - 5 } & & 質量均衡型 & 基本 & 剛性均衡型 \\
\hline \hline 質量 $[\mathrm{t}]$ & 300 & $300(\mu=1)$ & $949(\mu=\sqrt{10})$ & $3000(\mu=10)$ \\
\hline 剛性 $[\mathrm{kN} / \mathrm{mm}]$ & 490 & $49(\kappa=0.1)$ & $155(\kappa=1 / \sqrt{10})$ & $490(\kappa=1)$ \\
\hline
\end{tabular}



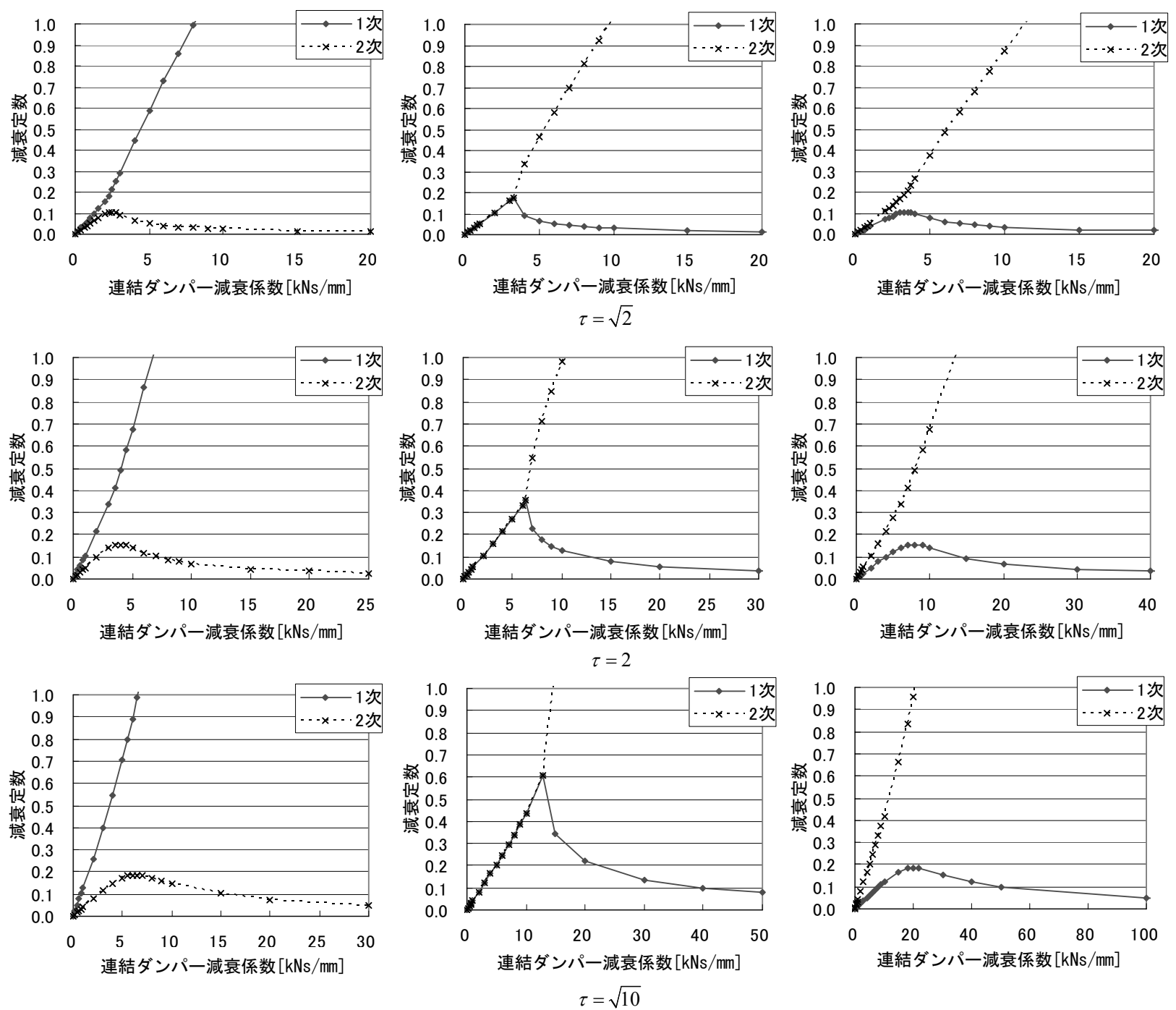

質量均衡型

基本モデル

図 9 固有周期比 $\tau=\sqrt{2}, 2, \sqrt{10}$ のモデルの減衰定数

剛性均衡型
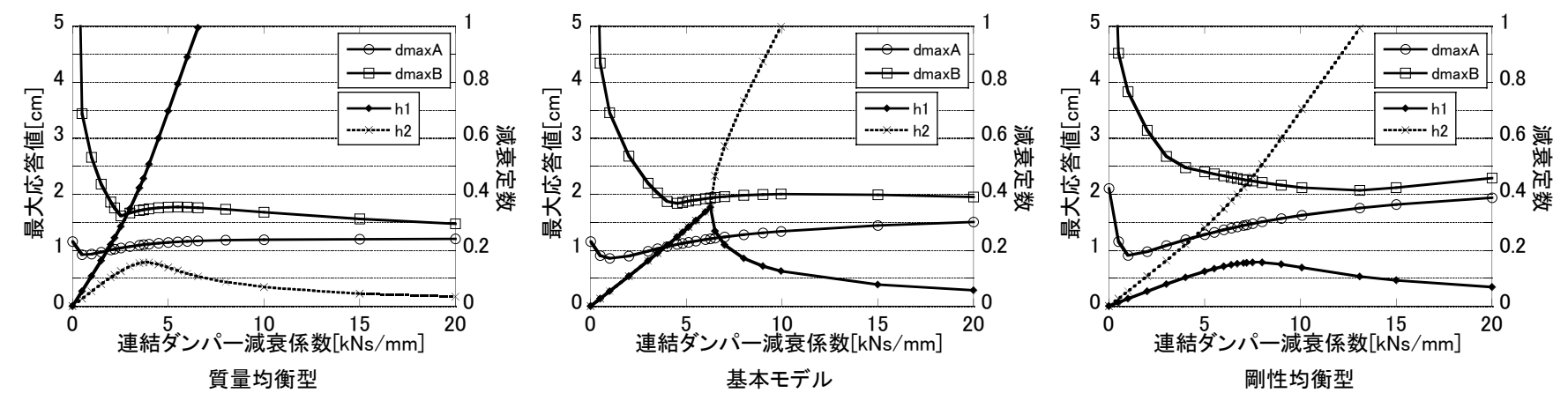

(a)Hachinohe 1968 NS（地動最大速度 $0.5 \mathrm{~m} / \mathrm{s}$ に規準化）
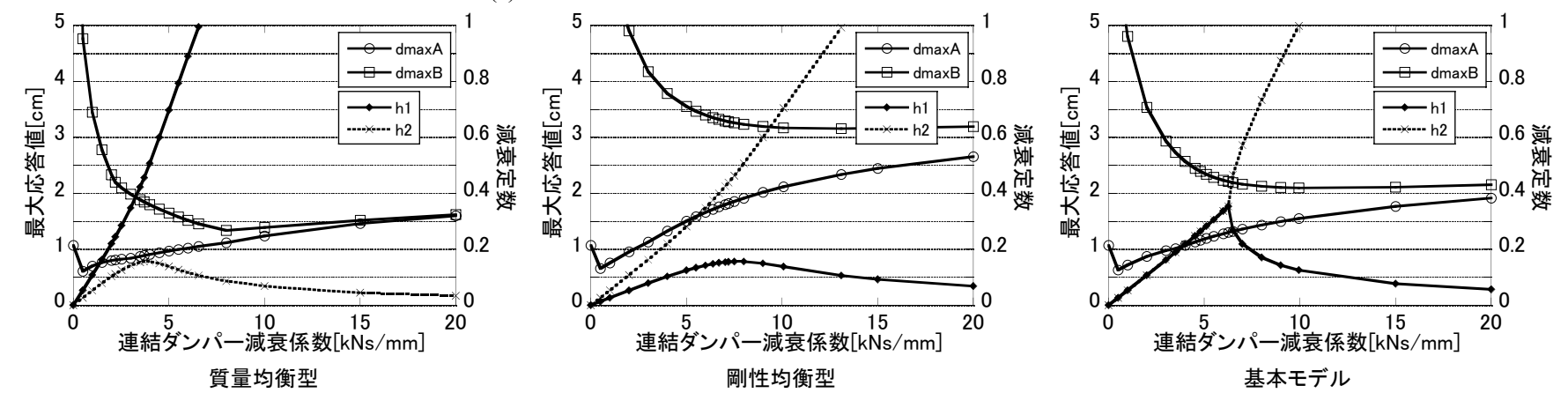

(b)JMA-Kobe $1995 \mathrm{NS}$ （地動最大速度 $0.5 \mathrm{~m} / \mathrm{s}$ に規準化）

図 10 地震時応答特性と減衰定数の変化の関係 ( $\mathrm{h} 1: 1$ 次減衰定数, $\mathrm{h} 2: 2$ 次減衰定数, $\mathrm{dmaxA}$ : 副系最大応答, $\mathrm{dmaxB}:$ 主系最大応答) 
(1)主系の最大応答（図中では $\mathrm{dmaxB}$ )を最小化する連結ダンパー

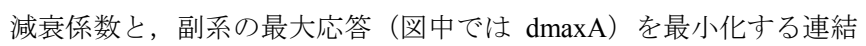
ダンパー減衰係数は大きく異なる。

(2)1 次または 2 次の減衰定数が極值となるような連結ダンパー減衰 係数と, 主系または副系の最大応答を最小化する連結ダンパー減衰係 数は一致しない. ただし, 減衰定数が極值となるような連結ダンパー 減衰係数における主系の最大応答は, 最小值とおおむね一致している といえる.

(3)長周期地震動的な性格が強い Hachinohe に対寸る主系の最大応 答の変化と, パルス性地震動的な性格が強い JMA-Kobe に対する主系 の最大応答の変化の傾向には, 有意な差がみられる. Hachinohe に対 しては, 主系と副系の関係によらず, 主系の最大応答の最小值はほぼ 等しいのに対して, JMA-Kobeに対しては, 主系の最大応答の最小值 は, 主系と副系の関係に大きく依存して変動する.

以上の観察結果より, 連結系における減衰定数は, 連結ダンパー減 衰係数が変化したときの地震時最大応答の変化の特性との間に一定 の相関性を有するものの, 地震時最大応答は主系と副系の質量比や剛 性比, 地震動の特性にも大きく影響を受けるため, 連結ダンパーの設 計においては,これらの影響を総合的に判断できる指標の導入が必要 であるといえる。

\section{8. 結論}

2 棟の建物をともに 1 質点とした 2 自由度の平面連結せん断質点系 モデルについて以下の結論を得た。

(1) 副系に対する主系の質量比 $\mu=M / m(\geq 1)$, 剛性比 $\kappa=K / k$ を軸 とする平面において, 連結ダンパーの減衰係数に対する全体系の減衰 定数の変動の様相を分類する領域分けが可能であることを示し, その 領域は 3 領域であることを明らかにした。

(2) 上記領域分けのうち, $\mu>\kappa$ の範囲では, 異なる 4 つの複素固有 值の実部および虚部の絶対值, またはそのどちらか一方が等しくなる 点（重複点）が存在することを明らかにした. また, その值を陽に誘 導した。

（3）上記領域分けの境界の 1 つを表す $\mu \kappa=1$ の関係を満たすモデル (基本モデル)では, 重複点まで 1 次および 2 次の減衰定数が等しく, 重複点を境に減衰定数が異なる 2 つの值に分岐することを明らかに した.また, 1 次および 2 次の異なる固有円振動数は, 重複点を境に 等しい值になることを明らかにした. 過減衰モードを含まない場合お よび含む場合の両者について, 上記 $2 つ の$ 性質が存在することを陽に 示した.

(4) 上記重複点を特徴付ける条件式を導いた. すなわち, それぞれの 建物モデルの質量および剛性と, 連結ダンパーの減衰係数, 連結モデ ルの減衰定数および固有円振動数間の関係を示した.

本論文では, 地震時応答については限られた数值例のみを示した。 応答スペクトル法を用いて地震時最大応答の評価を行う場合には, 減 衰定数による応答倍率や重複固有振動数は大きな影響を及ぼす. 本論 文で明らかにした固有振動や減衰定数の特性と, 地震時応答の関係に ついては稿を改めて詳細に論じる予定である.

\section{謝辞}

本研究の一部は科学研究費補助金(基盤 A（24246095）)による.こ こに記して謝意を表する。

\section{参考文献}

1) 井川 望, 山田祐司, 横山浩明, 橘英三郎： 2 棟連結による制振システム に関する研究, アクティブ制震 (振) シンポジウム論文集, pp.333-340, 1992.3

2) Luco, J. Enrique and De Barros, F. C. P. : Optimal Damping Between Two Adjacent Elastic Structures, Earthquake Engrg. Struct. Dyn., 27(7), pp.649-659, 1998.7

3) 䔖山 満, 安井 譲, 背戸一登: 連結制振の基本モデルにおける連結バネ とダンパーの最適解の誘導, 日本建築学会構造系論文集, No.529, pp.97-104, 2000.3

4) 䔖山 満, 安井 譲, 背戸一登: 多モード連結制振を対象とした連結バネ とダンパーの最適配置に関する研究, 日本建築学会構造系論文集, No.538, pp.79-86, 2000.12

5) 院山 満 : 定点理論による連結制振を対象としたパッシブ系の多モード最 適制振の設計法に関する研究, 日本大学学位論文, 2005

6) 諸岡繁洋，篠原達巳，御澤昇明，中島正愛 : 遊隙連結系の等価線形化と応 答制御一の適用，日本建築学会構造系論文集，No.587，pp61-68，2005.1

7) 辻 聖晃, 竹脇 出, 高橋宏治, 樫原健一：アウトフレームを用いた連結 制震構法による耐震補強（その 1 : 基本耐震補強特性）, 日本地震工学会大 会講演梗概集，pp.392-393，2005.11

8) 高橋宏治, 樫原健一, 辻 聖晃, 竹脇 出: アウトフレームを用いた連結 制震構法による耐震補強 (その 2 : 試設計例), 日本地震工学会大会講演梗 概集，pp.394-395，2005.11

9) 竹脇 出, 辻 聖晃 : 連結制震ダンパーを有する構造物群へ入力される地 震エネルギーの基本特性, 日本建築学会構造系論文集, No.616, pp.81-87, 2007.6

10) 楊 貴君, 岩崎良二, 高田毅士 : 連結構造物における定点理論に基づく質 量比一周波数比空間の領域分類と最適パラメターの誘導, 日本建築学会構 造系論文集, No.617, pp.71-76, 2007.7

11) 辻 聖晃, 竹脇 出: 外付けフレームとのダンパー連結による低層既存建 物の耐震補強構法, 日本建築学会構造系論文集, No.612, pp.55-62, 2007.2

12) 片岡隆広, 山本博之, 黒木安男, 樫原健一 : アウトフレーム連結制振構法 による耐震補強, その 1 構法概要及び試設計, 日本建築学会大会学術講 演梗概集，C-2，pp.615-616，2006.9

13) 高橋宏治, 太田崇士，太田 寬，樫原健一：アウトフレーム連結制振構法 による耐震補強, その 2 基本特性, 日本建築学会大会学術講演梗概集, C-2, pp.617-618, 2006.9

14) 岩佐裕一, 藤井 睦, 竹脇 出, 辻 聖晃 : アウトフレーム連結制振構法 による耐震補強, その 3 縮小モデルによる振動実験, 日本建築学会大会 学術講演梗概集, C-2, pp.619-620, 2006.9

15) 井川 望, 関谷英一, 竹脇 出, 辻 聖晃 : アウトフレーム連結制振構法 による耐震補強, その 4 振動実験結果の数值シミュレーション, 日本建 築学会大会学術講演梗概集, C-2, pp.621-622, 2006.9

16) 田原健一, 山崎真司, 見波 進: 履歷ダンパーを用いた連結制振構造の地 震応答低減効果，日本建築学会構造系論文集，No.621，pp49-56，2007.11

17) 伊藤 宰, 辻 聖晃, 吉富信太, 竹脇 出 : アウトフレーム連結制振構法 による既存建物而震補強の逆問題型アプローチ, 日本建築学会構造系論文 集, No.627, pp.725-732, 2008.5

18) 林 篤, 大迫勝彦, 和田 章, 高梨晃一：連結制振構造を適用した線路上 空建築物のエネルギーによる応答特性評価, 日本建築学会構造系論文集, 第 635 号, pp.55-63, 2009.1

19) 伊藤 宰, 辻 聖晃, 吉富信太, 竹脇 出 : アウトフレーム連結制振而震 補強のための連結ダンパーの合理的決定法, 日本建築学会構造系論文集, No.636, pp.273-281, 2009. 2

20) 林 篤, 大迫勝彦, 和田 章, 高梨晃一, 岩㟝和明, 鈴木勇 : 連結制振構 造を適用した線路上空建築物の設計と実測による性能評価, 日本建築学会 構造系論文集, No.648, pp299-307, 2010.2

21) 辻 聖晃, 中川大輔, 吉富信太, 竹脇 出: アウトフレーム型連結制振構法 におけるアウトフレーム及び連結ダンパーの応答低減率マップを用いた設 計法, 日本建築学会構造系論文集, No.648, pp337-346, 2010.2

22) 半田 潤, 吉富信太, 辻 聖晃, 竹脇 出 : 建物の平面配置効果を考慮し た 2 棟連結制振構法の特性解析, 構造工学論文集, Vol.57B, pp319-327, 2011

23) Kobori, T., Yamada, T. and Takenaka, T. : Effect of Dynamic Tuned Connection on Reduction of Seismic Response -Application to Adjacent Office Building-, Proc. 9WCEE, Tokyo-Kyoto, Japan, V, pp.773-778, 1988

24) 連結制振工法を共同住宅の耐震改修工事一適用，建築技術，No.682，p.54， 2006.11

25) Den Hartog, J. P. : Machanical Vibrations, 4th ed., McGraw-Hill, 1956

26) Veletsos, A. S. and Ventura, C. E. : Modal Analysis of Non-Classically Damped Linear Systems, Earthquake Engrg. Struct. Dyn., 14, pp.217-243, 1986 
Appendix 1 基本モデル $(\mu \kappa=1)$ における固有円振動数の性質（過 減衰モードを含む場合)

全ての固有值 $\lambda_{1}, \lambda_{2}, \lambda_{3}, \lambda_{4}$ のうち, $\lambda_{1}, \lambda_{2}$ が複素数であり, $\lambda_{3}, \lambda_{4}$ が 実数の場合を考える. このとき，代数方程式の性質から， $\lambda_{1}$ と $\lambda_{2}$ は 共約なペアとなる. すなわち, $\lambda_{1}=\lambda_{2}{ }^{*}$ となる. また, $\lambda_{3}>\lambda_{4}$ とする. このとき, 固有値と固有円振動数, 減衰定数の関係を用いると, 固有 值は次のように表すことができる.

$$
\begin{array}{ll}
\lambda_{1}=-h^{(1)} \omega^{(1)}+\omega^{(1)} \sqrt{1-\left(h^{(1)}\right)^{2}} \mathrm{i}, & \lambda_{2}=-h^{(1)} \omega^{(1)}-\omega^{(1)} \sqrt{1-\left(h^{(1)}\right)^{2}} \mathrm{i} \\
\lambda_{3}=-h^{(2)} \omega^{(2)}+\omega^{(2)} \sqrt{\left(h^{(2)}\right)^{2}-1}, \quad \lambda_{4}=-h^{(2)} \omega^{(2)}-\omega^{(2)} \sqrt{\left(h^{(2)}\right)^{2}-1}
\end{array}
$$

実固有值と減衰定数, 固有円振動数の関係としては, (A1c, d)式を用 いるものとする. (A1a-d)式より次式を得る。

$$
\begin{aligned}
& \lambda_{1} \lambda_{2}=\left(\omega^{(1)}\right)^{2}, \quad \lambda_{3} \lambda_{4}=\left(\omega^{(2)}\right)^{2}, \quad \lambda_{1}+\lambda_{2}=-2 h^{(1)} \omega^{(1)}, \\
& \lambda_{3}+\lambda_{4}=-2 h^{(2)} \omega^{(2)}
\end{aligned}
$$

この式は，過減衰モードがない場合の(22)式と表現上は全く同じであ る.したがって, これ以降の式展開は, 過減衰モードがない場合と同 じとなる.

次に, 全ての固有值が実数の場合を考える.ただし $\lambda_{1}>\lambda_{2}>\lambda_{3}>\lambda_{4}$ とする.このとき, どの固有值をぺアとするかには任意性があるため, 例えば $\lambda_{1} と \lambda_{2}, \lambda_{3}$ と $\lambda_{4}$ をそれぞれペアとする. このとき, 固有值 と固有円振動数, 減衰定数の関係を用いると, 固有值は次のように表 すことができる.

$$
\begin{aligned}
& \lambda_{1}=-h^{(1)} \omega^{(1)}+\omega^{(1)} \sqrt{\left(h^{(1)}\right)^{2}-1}, \quad \lambda_{2}=-h^{(1)} \omega^{(1)}-\omega^{(1)} \sqrt{\left(h^{(1)}\right)^{2}-1} \\
& \lambda_{3}=-h^{(2)} \omega^{(2)}+\omega^{(2)} \sqrt{\left(h^{(2)}\right)^{2}-1}, \quad \lambda_{4}=-h^{(2)} \omega^{(2)}-\omega^{(2)} \sqrt{\left(h^{(2)}\right)^{2}-1}
\end{aligned}
$$

(A3a-d)

(A3a-d)式より次式を得る.

$$
\begin{aligned}
& \lambda_{1} \lambda_{2}=\left(\omega^{(1)}\right)^{2}, \quad \lambda_{3} \lambda_{4}=\left(\omega^{(2)}\right)^{2}, \quad \lambda_{1}+\lambda_{2}=-2 h^{(1)} \omega^{(1)}, \\
& \lambda_{3}+\lambda_{4}=-2 h^{(2)} \omega^{(2)}
\end{aligned}
$$

この式も, 過減衰モードがない場合の(22)式と表現上は全く同じであ る.したがって, これ以降の式展開は, 過減衰モードがない場合と同 じとなる.

結局, 過減衰モードがある場合についても，6 節と同様の特性 1 4 が成立する。

なお, $\mu \kappa=1$ で過減衰モードがある場合の重複点における固有值は, (A3)式で $h^{(1)}=h^{(2)} \equiv h, \quad \omega^{(1)}=\omega^{(2)} \equiv \omega$ とすると,

$$
\lambda_{1}=\lambda_{3}=-h \omega+\omega \sqrt{h^{2}-1}, \quad \lambda_{2}=\lambda_{4}=-h \omega-\omega \sqrt{h^{2}-1}
$$

となり, 「2 組の重複した実固有值に分けられる」ことがわかる.

\section{Appendix 2 連結ダンパー減衰係数 $c$ が無限大となったときに, 減衰 定数のうちの 1 つはゼロに収束すること, および, 少なくとも 1 つの 極値をもつことの証明}

(6a)式より, 連結ダンパー減衰係数 $c$ が無限大のときには，少なく とも一つの固有值 $\lambda$ は無限大に収束する必要があることがわかる.

一方, (6d)式より, 4 つの固有值の積は必ず有限であるから, $c$ が無 限大のときには, 少なくとも一つの固有值はゼロに収束する必要があ ることもわかる，そこで，cが無限大のときに， $\lambda_{1}$ を無限大に収束す る固有值， $\lambda_{2}$ をゼロに収束する固有值であると仮定する. 次に $(6 \mathrm{~b})$ 式と上の仮定より, $c$ が無限大のときには， $\lambda_{3}=-\lambda_{4}$ となる必要があ ることとなる. 減衰定数と固有值の関係を示した $(3 b)$ 式に, 上記の組
み合わせを代入すると， $\lambda_{1}$ と $\lambda_{2}$ の組み合わせから計算される減衰定 数は無限大に, $\lambda_{3}$ と $\lambda_{4}$ の組み合わせから計算される減衰定数はゼ口 に収束することが示される.

また， $\lambda_{3}$ と $\lambda_{4}$ の組み合わせから計算される減衰定数は， $c=0$ では 明らかにゼロ， $c>0$ ではある有限值であり,$c$ が無限大のときにはゼ ロに収束するため, 少なくとも一つの極值を持つことは明らかである。 